\title{
Integrating the Innovation Management Methodology Into the Existing Quality Management System of a Machine-Building Enterprise
}

\author{
Vyacheslav Miroshnikov ${ }^{1}$, Anna Morozova ${ }^{2, *}$, and Tatyana Svetlichnaya ${ }^{3}$ \\ ${ }^{1}$ Bryansk State Technical University, 241035 Bryansk, Russia \\ ${ }^{2}$ Bryansk State Technical University, 241035 Bryansk, Russia \\ ${ }^{3}$ Bryansk State Technical University, 241035 Bryansk, Russia
}

\begin{abstract}
The problem of integrating European standards in the field of innovation management (SIM) into the existing quality management systems (QMS) of organizations is considered. The authors analyze the most relevant developments of the methodological foundations of innovation management, as a promising direction of scientific knowledge, and research aimed at summarizing the practical experience of its implementation in various sectors of the economy and the service sector. Particular attention is paid to analyzing scientific publications in the field of industrial innovation. The main directions of integrating innovation management methodologies into the systems of quality management of products and services operating at enterprises and organizations are proposed. The conceptual model of the innovation management system is presented, which contains its key elements. It is shown that for industrial enterprises and manufacturing firms it is inappropriate to have two different systems (QMS and SIM), which tend to the same goal namely to improve the product quality. A process model of innovation management that implements the principle of quality management called "Improvement" is proposed, and the description of the model is given. The specificity of implementing QMS and SIM integration processes at Russian enterprises of the machine-building complex is revealed.
\end{abstract}

\section{Introduction}

Currently, special attention is paid to solving issues in the management decision-making system [1], to introducing and developing TQM techniques in industrial enterprises [2], to carrying out new optimization techniques and implementing quality control procedures in the quality management systems (QMS) of organizations [3] and industrial enterprises [4, $5,6]$ of various industries, including: construction $[7,8]$, medicine $[9,10]$, oil refining and gas industry [11], etc.

\footnotetext{
* Corresponding author: niotiostu@gmail.com
} 
In 2015, the European Committee for Standardization CEN/TC-389 [12] developed a set of European standards in the field of innovation management (CEN/TS 16555 Innovation Management - Part 1: Innovation Management System [13]), which was finalized, approved and recommended for implementing in organizations.

In this regard, in recent years, the work of the scientific community has been aimed at developing the methodological foundations of innovation management as a promising direction of scientific knowledge $[14,15,16,17,18]$, as well as at summarizing the practical experience of its implementation in various sectors of the economy and services $[19,20,21,22]$. A special role in the given study is the analysis of scientific publications in the field of the industrial innovation [23, 24, 25].

\section{Theory}

Innovation management is the use of techniques and methods that are meant to justify making rational management decisions. Combining these methods and techniques constitute a special methodology for innovation management. In modern market conditions, innovation management is one of the important directions in the development and success of an enterprise.

At the same time, the issues of practical application of innovation management at machine-building enterprises with the presence of already functioning quality management systems (QMS) remain insufficiently developed and researched. This study was meant to solve this problem.

The innovation management system ensures the implementation of activities to create innovations on a continuous basis, regardless of the company size.

Fig. 1 presents the conceptual model of the innovation management system, which contains its key elements [26].

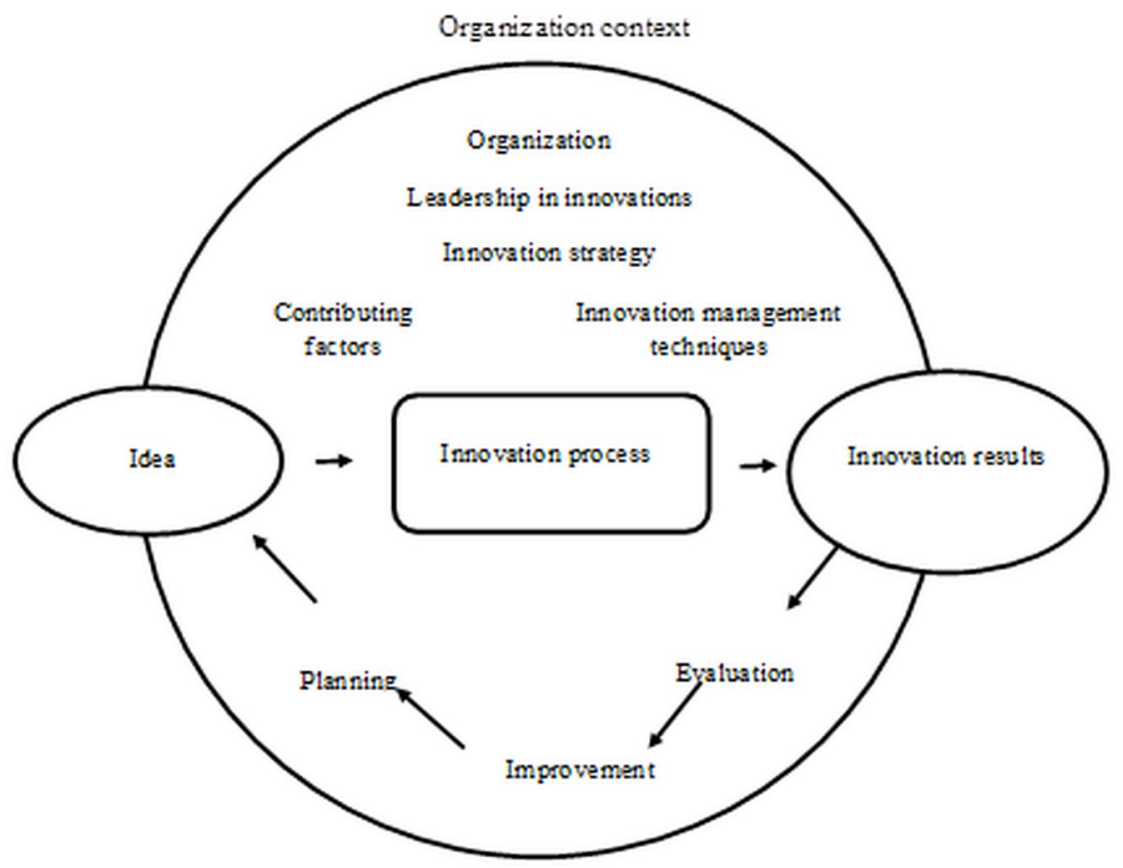

Fig. 1. The conceptual model of the innovation management system. 
In the Russian Federation in 2014-2015 on the basis of the CEN/TC international standards complex [13], the family of national standards "Innovation Management" was developed and approved, and the work began on certifying innovation management systems (SIM) [27].

At the same time, practice has shown that it is inappropriate for enterprises to have two different systems (QMS and SIM), which strive for the same goal namely to improve the product quality. In this regard, for functioning and developing industrial enterprises at this stage, the problem of having methodological support for implementing the integration process of the innovation management system which is under formation and the existing quality management system is becoming topical and vital.

Introducing innovation management under the existing certified quality management system was considered by the authors as a modern and effective methodology for implementing the well-known principle of quality management called "Improvement" (in particular, "Continuous Improvement") [27].

To do this, the authors propose to consider each of the QMS processes as an improvement (refinement) by using the following subsystems of innovation management techniques [13].

Strategic monitoring and forecasting management provides both decision support with reliable information and knowledge, and value analysis for the organization: understanding customers' current and future needs and the market; considering the competitive environment; understanding the organization limitations, opportunities and risks; identifying new markets, cooperation, services, products and technologies; technological and regulatory changes; new standards; sources of financing, etc.

Innovative thinking provides developing a special approach that involves each employee of the organization in the innovation process; it is developed gradually on the basis of traditional techniques associated with the process of designing material objects.

Intellectual property management through controlling, protecting and using intangible assets owned by the author, provides freedom of authors' action in developing innovative products, their protection against counterfeit and violations of property rights.

Collaboration management ensures implementing interaction processes of individual groups within the organization and using external knowledge potential (team collaboration, community collaboration, networking, open innovations); this, in general, contributes to increasing the potential of creativity and the success of corporate interests in the field of innovation.

Creativity management within an organization can be implemented in several directions: creating an innovation strategy focused primarily on promoting creativity; providing creative and creativity-stimulating leadership; generating ideas; documenting ideas, etc.

A detailed description of various methods of innovation management is given in the family of Russian national standards "Innovation Management" [27].

\section{Results}

The authors' studies were carried out in relation to the Russian enterprises of the machinebuilding complex.

The authors have developed a scheme for integrating innovation management techniques with the existing quality management systems of organizations and enterprises and presented it in the form of a process model in Fig. 2 [28]. The left column gives the names of the processes of the QMS in accordance with the requirements of the Russian standard 9001-2015 [27]; the right column lists the methods of innovation management 
described above; connecting lines having circles with numbers show the possible directions of applying these techniques to improve specific QMS processes, a list of which is given later in the text.

The main directions of improving the implementation of processes in existing QMS enterprises through their integration with the methods of innovation management are as follows:

1. The organization environment that is assessing internal and external factors to achieve the planned level of quality results based on implementing strategic forecasting management

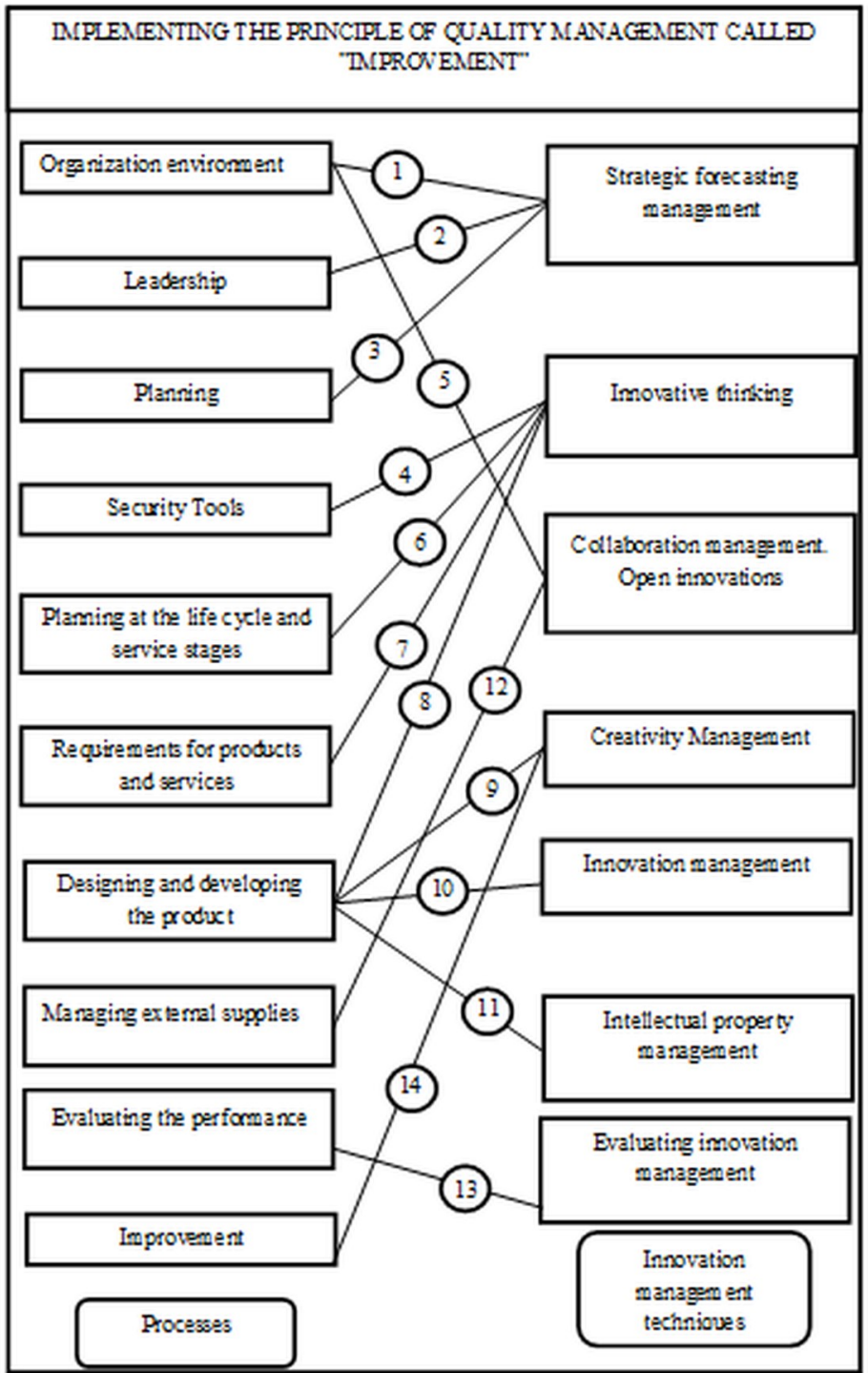

Fig. 2. The process model of innovation management. 
2. Leadership that is implementing the organization quality policy, which determines certain levels and types of improvement in carrying out QMS processes, which ensures its success and competitiveness in the market.

3. Planning that is a strategy to ensure the organization innovative development.

4. Means of support that is a system for managing differentiation and integration of intracorporate and externally acquired knowledge required to meet the organization present and future needs, which is ensured by dramatic changes in staff qualifications through its training by using interactive methods, the purpose of which is to create the foundations of employees' innovative thinking.

5. Cooperation management that is a factor of identifying and creating conditions for understanding all stakeholders' needs and expectations other than contractual customers' and end users' needs and expectations, which allows accumulating not only internal, but also external ideas within the organization.

6. Planning at the stages of the life cycle of products and services that is a procedure for forming and implementing a system of processes necessary for developing and producing innovative products at different stages of its life cycle, taking into account the risks and potential changes that may occur during its production.

7. Requirements for products and services that is a document agreed with the responsible executives, confirming the organization ability to produce the proposed innovative products.

8. Design and product development that is making an action plan for a project to create an innovative product or service, which includes an analysis of constraints and risks, resource requirements, and the definition of contractors' functions and responsibilities.

9. Management of creativity in designing and developing products provides control over the process of integrating ideas that can be used to carry out innovative products or services with a specific system of the given characteristics.

10. Using schemes and maps of the strategic and operational level of innovation management in the organization under designing and developing products that is a method of structuring processes from a systematic approach (for example, a roadmap, a documented decision to launch a project, etc.), which allows the customer to control "the route of implementing" the project by the performer.

11. Intellectual property management that is a tool to support innovation through authorizing ideas and methods used to develop innovative products or services, and solving problems of intellectual property protection, as well as optimizing the cost of support and acquisition of intellectual property.

12. Management of external suppliers that is a factor optimizing the influence of all stakeholders (suppliers and partners) on achieving the organization planned results in the field of innovation.

13. Assessing the results of innovation activities of the QMS that is a factor in improving the implementation of the processes of monitoring, measuring, analyzing and evaluating the effectiveness of the quality management system by expanding and deepening the initial information about the innovations performed.

14. Improvement that is a result of integrating the innovation management methods and processes of the existing QMS at the enterprise: the presence and phased implementation of a base of new ideas by increasing staff creativity, the level of its intra-corporate interaction and interest in the results of the joint activities.

\section{Conclusion}

Studies show that integrating the innovation management methodology and product quality management systems provides enterprises with the following benefits: accelerating the 
increase in output, increasing revenues and profits from innovations; new thinking and new values for the organization; obtaining additional benefits as a result of better understanding of future market needs and opportunities; assisting in identifying and reducing risks; increasing the organization collective creativity and intellectual potential; obtaining additional benefits as a result of cooperating with partners in the innovation process; motivating employee's involvement in the company innovative activity and stimulating the teamwork.

At the same time, the specifics of implementing the integration processes at Russian enterprises of the machine-building complex are characterized by a high level of inertia in making such decisions, which is especially characteristic of enterprises created before the 90 s of the $20^{\text {th }}$ century and retaining a large number of employees.

\section{References}

1. Kh. Mullakhmetov, Problems and Perspectives in Management (Sumy, 2016)

2. B.G. Dale, J.J. Plunkett, Quality Costing (Routledge, London , 2017)

3. M.N. Roy, S.S. Saha, In: Statutory Auditors' Independence in Protecting Stakeholders' Interest (Palgrave Macmillan, Cham, 2018)

4. W. Huang, L. Shu, W.H. Woodall, K.-L. Tsu, J. IIE Trans., 48, 759 (2016)

5. H.H. van Rossum, H. Kemperman, CCLM, (2017)

6. M.F. Vardaro, L. Belabbassi, L. Garzio, M. Smith, F. Knuth, J. Kerfbot, S. Lichtenwalner, M.F. Crowley, OOI data quality procedures and tools building on the first year of operations (IEEE, N.17452661, 2017)

7. W.M. Ghannoum, N.K. Alotaibi, J. Garcia, Ch.H. Kim, Y. Kim, D. Pudleiner, K Quinn, N. Satrom, W. Shekarchi, W. Sun, H. Wang, J.O. Jirsa, Inter. Conc. Abstr. Port., 327, 43.1 (2016)

8. M. Kitazume, M. Grisolia, E. Leder, I.P. Marzano, A.A.S. Correia, P.J.V. Oliveira, H.Åhnberg, M. Andersson, S. and Found., 55:4, 761 (2015)

9. L. Hui, Y. Bin, Y. Xin, Chin. J. Clin. Thor. Card. Surg., 26:1, 35 (2019)

10. W. Punyalack, P. Graham, T. Badrick, CCLM, (2018)

11. C. Morais, R. Moura, M. Beer, J. Lewi, In : Safety and Reliability of Complex Engineered Systems (Podofillini et al., Taylor \& Francis Group, London, 2015)

12. CEN/TC, 389, (2015)

13. CEN/TS 16555-1:2013, Innovation Management. Part 1. Innovation Management System, (2015)

14. R. Adams, J. Bessant, R. Phelps, Inter. J. Man. Rev., 8:1, 21 (2006)

15. M.J. Donate, J.D.S. de Pablo, J. Bus. Res., 68:2, 360 (2015)

16. S. Roth, D. Schneckenberg, C.-W. Tsai, Creat. and Innov. Manag., 24:2, 300 (2015)

17. G. Santoro, D. Vrontis, A. Thrassou, L. Dezi, Techn. Forec. and Soc. Chan., 136, 347 (2018)

18. J.M. Utterback, Mastering the Dynamics of Innovation: How Companies Can Seize Opportunities in the Face of Technological Change, (1994)

19. E. Leonidou, M. Christofi, D. Vrontis, A. Thrassou, J. Bus. Res., (2018)

20. J. Nieves, M. Segarra-Ciprés, Tour. Manag., 46, 51 (2015)

21. A. Oke, Inter. J. Oper. \& Prod. Manag., 27:6, 564 (2007) 
22. M. von Zedtwitz, S. Corsi, P. V. Søberg, R. Frega, Prod. Innov. Manag., 32:1, 12 (2015)

23. Ph. Aydalot, D. Keeble, High Technology Industry and Innovative Environments. The European Experience (Routledge, London, 2018)

24. M. Dodgson, Technological Collaboration in Industry. Strategy, Policy and Internationalization in Innovation (Routledge, London, 2018)

25. F.A. Johne, Industrial Product Innovation (Routledge, London, 2018)

26. State standard ISO 9001:2015. Quality management systems. Requirements. (Standartinform, Moscow, 2015)

27. L.K. Stegnienko, A.E. Petrosyan, E.V. Dryuk, J.Age of Qual., 4 , 44, (2016)

28. V.V. Miroshnikov, G.V. Efimova, T.V. Svetlichnaya, Qual. and Life, 1, 41 (2019) 